Article

\title{
Connecting Public Policies for Family Farmers and Women's Empowerment: The Case of the Brazilian Semi-Arid
}

\author{
Emily Aparecida Ferreira Brandão ${ }^{1,2, *}$, Thiago da Rocha Santos ${ }^{3}$ and Stephan Rist ${ }^{1,2,4}$ \\ 1 Institute of Geography, University of Bern, 3012 Bern, Switzerland; stephan.rist@giub.unibe.ch \\ 2 Centre for Development and Environment, University of Bern, 3012 Bern, Switzerland \\ 3 Rural technical assistant, coordinator of the Cooperativa Sertão Forte de Casa Nova e Região (COOAF), \\ Casa Nova, Bahia 47300-000, Brazil; thiagorocha1602@gmail.com \\ 4 UNESCO Chair for Sustainable Mountain Development, University of Bern, 3012 Bern, Switzerland \\ * Correspondence: emilyfbrandao@gmail.com
}

Received: 2 June 2020; Accepted: 20 July 2020; Published: 24 July 2020

\begin{abstract}
The role played by women in worldwide food production and food security has reinvigorated debates about the recognition of women's rights in the rural sector regarding better working conditions and the reduction of gender inequalities. In the 1980s, the social movement in Brazil restructured the politics in the agrarian sector by integrating farmers' rights and women's demands. Against this background, the objective of this study is to analyze, through the actors' perspectives, whether and how the combination of public policies for family farmers affected the socio-economic and political empowerment of women. Our case study covers family farmers from traditional communities located in the Brazilian semi-arid. The results show that women achieved economic stability by participating in public food procurement programmes. In addition, access to cisterns released women from the daily work of collecting water. Women became more involved with political issues, increasing participation in institutions such as NGOs, associations and cooperatives. Among the negative aspects, the study found that the sexual division of labor increased within the household context, and, despite being fundamental for ensuring household food security, women still struggle to have access to the means of production.
\end{abstract}

Keywords: food system; public policies; fundo de pasto communities; women's empowerment

\section{Introduction}

The movement towards gender equality has reinvigorated debates surrounding the role played by the state and citizens in the search for an equal society. Women are key actors in the food systems since they form about half of the worldwide agricultural workforce and are responsible for managing income and ensuring adequate nutrition for all household members [1]. However, gender gaps regarding access to income and ownership of the productive resources in the rural sector are enormous. Gender imbalances negatively influence women's empowerment and, consequently, erode household food security.

The resurgence of social movements marked the 1980s in Brazil, and the main struggle was for the restoration of democracy after 21 years of military dictatorship. Along with the process of re-democratization, urban and rural feminist movements emerged, claiming rights for women [2]. The main demands of female agricultural workers were the recognition of the farming profession and the rights arising from this recognition, such as social rights (especially the right to full retirement pension and maternity wages). In addition, they requested the right to organize in unions, independent of the participation of their parents, brothers or husbands [3,4]. 
Social movements pushed for changes in political-institutional scenarios [5]. In this period, society and the state narrowed dialogues, leading to the creation of new spaces for social participation. In addition, further political actors emerged, and comprehensive public policies were created and institutionalized, affecting the socio-economic conditions for the female population [6]. The 1988 Brazilian Constitution was the initial milestone for the recognition of family farming as a professional category since it included family farmers in the social security retirement programme. In addition, women were guaranteed the same rights enjoyed by men, such as the right to rural social security and participation as beneficiaries of public policies [7]. Despite the constitutional advances, food public policies targeted at family farmers and female rural workers were institutionalized at the federal level during the government of former president Luiz Inácio Lula da Silva (2003-2011).

In line with the trend for more comprehensive and inclusive policies, the 2030 Agenda for Sustainable Development, adopted by the United Nations General Assembly in 2015, proposed 17 sustainable development goals (SDGs). The agenda is very clear on the need for gender equity and women's empowerment worldwide by 2030, as defined in objective 5 [8]. This quest for broad rights for women requires public policies and other initiatives that guarantee personal and financial autonomy, access to education, health and means of production, among other demands.

Public policies express the contradictory tendencies of society; therefore, they may not reach the determined goal. The public policy's efficiency depends on a combination of factors, such as the political context, social conventions, intra-family relationships, institutions and the interactions they have with the affected actors $[9,10]$. The incorporation of women into the socio-economic dynamic relies on public policies that encourage women's empowerment through access to resources (credit, land, training, information, technology, etc.), education and participation in decision-making spaces.

The rising body of work on gender in the context of agricultural development has explored subjects such as how female empowerment can lead to sustainable development $[1,11,12]$ and how women's empowerment changes household dietary behaviors and contributes to reaching food security [13,14]; some reports also show that gender equality is in line with food systems' sustainable practices in climate change scenarios $[15,16]$. There is a group of Brazilian studies that seek to understand how the participation of rural women in public policy building contributes to more sustainable practices [2] and others that analyze how access to public policies contributes to the economic autonomy and empowerment of women in public and private spaces [17-19].

Despite the pertinent amount of work relating to women's empowerment and access to public policies, few empirical analyses have been conducted considering how public policies aimed at rural development can change social structures. Therefore, this study seeks to fill the above research gap by analyzing, through the actor's perspective, whether and how the combination of public policies targeted at family farmers affects the socio-economic and political empowerment of women. We seek to analyze the extent to which transformations in women's conditions regarding income, housework, dedication to food and water security and political involvement have been translated into empowerment at the personal and relational (household and community) levels.

We focus our analyses on the case of the rain-fed family farmers' food system, situated in the Brazilian semi-arid (state of Bahia), where fieldwork was conducted from October 2018 to January 2019. Three traditional communities of family farmers, named fundo de pasto communities, took part in this study (Melancia, Riacho Grande and Ladeira Grande). The main characteristic of these communities is the communal land use for food production for self-consumption and commercialization. Women are fundamental in these communities as they are responsible for ensuring the food and water security at the household level, in addition to contributing actively to the struggle for land.

Data were collected through focus groups, semi-structured interviews, questionnaires with key actors and participant observation. The main questions that guided us in this research were (1) did public policies affect the socio-economic and political condition of women, and if so, how? and (2) to what extent have public policies empowered women and changed their status within the food system? 


\section{Conceptual Framework}

Within the political discourse, public policies have the ability to innovate the social context, improving outcomes and opportunities towards more equitable social dynamics [20,21]. The authors refer to the capacity of governmental policies, programmes and projects to offer opportunities to "invisible" individuals and include them in the dynamics of socio-economic growth and development. In the rural context, public policies are implemented to tackle a variety of issues, such as rural exodus, lack of diversification of agricultural production, mediation of socio-environmental and inter-generational conflicts, improvement of access to the market and to the means of production and reduction of the sexual division of labor that places women in a position of subalternity. By intervening in the socio-economic context, public policies can trigger a social dynamic to correct old and new injustices [22], bringing to light historically marginalized groups. Social dynamics refer to the way in which social interaction occurs and resonates in the intervention strategies of the actors in a territory [23-25].

Social dynamics play a decisive role in shaping different social groups as they set or remove limits to inclusion or exclusion. The concept of social exclusion is understood in different ways. Some scholars define social exclusion as inadequate social participation, lack of social integration and lack of power [26-28]. "Social exclusion is a complex and multi-dimensional process. It involves the lack or denial of resources, rights, goods and services, and the inability to participate in the normal relationships and activities, available to the majority of people in a society, whether in economic, social, cultural, or political arenas". It affects both the "quality of life of individuals and the equity and cohesion of society as a whole" [29] (p. 9). Thus, social inclusion would be the counterpoint to the concept mentioned above, constituting the ability of people to fully appreciate society [29], through measures that promote "the realization of rights, participation in social affairs, access to education, health and care services, basic infrastructure services and housing, and disposable income" [30].

Promoting gender equality is a way of achieving social inclusion, by integrating and supporting women's empowerment as an instrument of poverty and hunger reduction and respect for fundamental rights and citizenship. From the feminist perspective, women's empowerment refers to the process of achieving self-determination autonomy, unfolding in the liberation of women from the bonds of gender and patriarchal oppressions [31]. In addition, women's empowerment concerns the transformation of the lives of women and girls from a former condition in which they had limited power to one in which their power is enhanced [32]. The transformation can take place within the personal level and relational level [33]. The changes at the personal level refer to the way in which women see themselves and how they consider their role in society. The changes at the relational level are related to surrounding network relationships, including shifts within the household and the community [33].

The expansion of women's participation in the political and economic structures of society implies better conditions for global food security [34,35]. We follow Food and Agriculture Organization (FAO), stating that "Food security exists when all people, at all times, have physical and economic access to sufficient, safe and nutritious food that meets their dietary needs and food preferences for an active and healthy life" [36]. Beyond food security, food systems' contributions encompass their role in creating jobs, infrastructure, stabilizing livelihoods and market, generating income, reducing poverty and inequality among stakeholders and between different territories and preserving environmental integrity [37]. Food security can be interpreted as an outcome of food systems [38]. Food systems are defined as interconnected but independent networks of stakeholders (NGOs, public and private organizations, citizens, financial institutions and companies) coexisting in a geographic space (region, state, multinational region), which contribute directly or indirectly to the generation of flows of goods and services that are oriented towards supplying the food needs of groups of consumers located in the same geographic space or elsewhere [39]. The better the understanding of the food system's outcomes, the easier it is to assess food sustainability. The concept of food sustainability is based on five pillars: food security, the right to food, the reduction of poverty and inequality, environmental integrity and social-ecological resilience [38]. 
Figure 1 summarizes a conceptual framework that underpins this research. It provides a perspective on the public policies and transformation processes towards women's empowerment and the interactions between actors that may influence social dynamics. The conceptual framework was taken into consideration for analyzing the contribution of public policies to the transformation of women's socio-economic and political status in terms of income, housework conditions, work for ensuring food and water security and political engagement. In our scenario, women's empowerment would result from personal and relational changes, in terms of becoming aware of their importance for society and community and transforming oppressive gender relationships into balanced relationships.

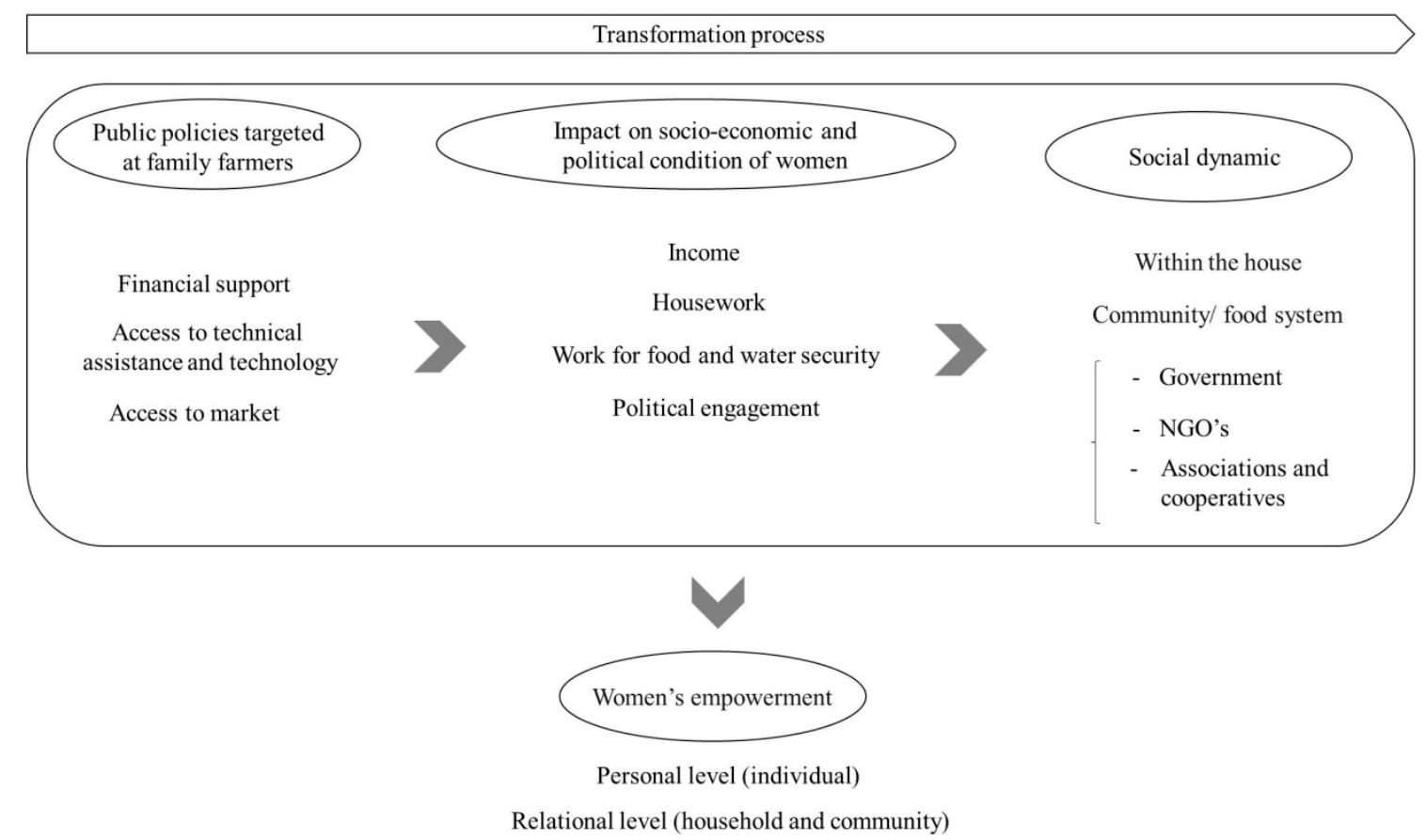

Figure 1. Conceptual framework.

Our study hypothesizes that public policies have the potential to cause social dynamics by providing subsidies for the empowerment of a historically neglected social group. In this sense, public policies would affect the social, political and economic status of women, empowering and encouraging them to reconfigure their role within the community and their relationships with individuals (partners, family members and community members). Women must acknowledge the ideology that legitimizes males and understand how oppression is perpetuated, by questioning the social construction that subordinates them (changes at the personal level) and then adopting transformative attitudes to reconfigure surrounding relationships (changes at relational level). We believe that a sustainable rural development strategy should consider gender debates as a way of generating equity among actors in the food system, reducing food insecurity, poverty and inequality.

\section{Public Policies for Family Farmers of the Brazilian Semi-Arid (Bahia)}

One of the positive consequences of the Brazilian social movements of the 1980s was the recognition of family farmers as part of the agrarian structure. To improve family farmers' living conditions, the government started to implement socio-economic policies and ecological instruments [6]. In this sense, women's struggle and demands also became visible in the political scene, moving from the idealistic equality of gender to real equality through the recognition of women's rights [3]. In this section, we will present the main features of the key food policies that were implemented in the study area, setting the stage to investigate whether and how these policies have led to higher degrees of empowerment in women. 


\subsection{Financial Support}

The Bolsa Familia programme was created in 2003 by the federal government to work as a conditional cash transfer for families living in extreme poverty (monthly per capita income up to $R \$ 85.00$ ) and poverty (monthly per capita income of between $R \$ 85.01$ and $R \$ 170.00$-approximately, US $\$ 14.76$ and US\$29.52, respectively) [40]. The payments are directed to the head of the family and, preferably, the woman. Bolsa Familia is not exclusively aimed towards family farmers, but it ends up encompassing a considerable part of this group as they are the most vulnerable to poverty. Between 2007 and 2011, it was identified that more than $90 \%$ of the Brazilian rural population benefited from the Bolsa Familia [41].

Among the conditionalities for receiving the conditional cash transfers are the supervision of the family's health condition and controlling the children's education. The beneficiary must report to the federal government the vaccination of children up to seven years old, the prenatal examinations of pregnant women aged from 14 to 44 years old and children's attendance at school [40].

\subsection{Technical Assistance and Technology Transfer}

In 2010, the Technical Assistance and Rural Extension National programme (Assessoria Técnica e Extensão Rural, ATER) was created to disseminate specific technical knowledge to family farmers, aiming at improving their ability to work together through productive groups and promoting new technologies including sustainable practices [42]. Since the Bahia state government is responsible for the definition and implementation of the ATER, the government opted to outsource this service to NGOs and other private entities, which are contracted through public calls. Linked to ATER, the Programme for the Productive Organization of Rural Women (Programa de Organização Produtiva de Mulheres Rurais, POPMR) was created to provide technical assistance exclusively to women. It seeks to encourage the formation of women's working groups, aiming to improve their participation in the rural economy. The programme also offers knowledge to promote women's involvement in the transition to agro-ecology.

With regard to the promotion of technology, the One Million Cisterns for Drinking Water (Um Milhão de Cisternas Rurais, P1MC) programme stands out for its importance in tackling water scarcity. The programme was created in 2003 to offer cisterns to family farmers situated in the semi-arid region, so that rainwater could be stored for domestic consumption and crop production [43]. To benefit from cisterns, the families must meet the following criteria: (1) live in the rural area; (2) have a per capita income of up to $\mathrm{R} \$ 154.00$ per month $-15 \%$ of the current Brazilian minimum wage., (3) have no access to water; (4) have a house with a roof to capture the rainwater; (5) must not be assisted by another programme with the same purpose [43].

\subsection{Food Security and Mediated Market}

The National School Feeding Programme (Programa Nacional de Alimentacão Escolar, PNAE) was launched in the second half of the 1900s, having been transformed throughout the years from a regional scope to a national programme. In 2003, it assumed its current shape, which aims to offer school meals and nutritional education to students at all stages of primary public education. At least $30 \%$ of the PNAE budget must be directed to acquiring food from the local family farm sector [44]. To participate in this programme, the family farmer must be connected to farmer associations or cooperatives.

The Food Procurement Programme (Programa de Aquisição de Alimentos, PAA) was created in 2003 to promote access to food in quantity, quality and necessary regularity for populations in situations of food and nutritional insecurity, as well as to promote economic and social inclusion by fomenting sustainable production, commercialization and consumption through the strengthening of family farming [45]. Through PAA, the government (federal, state and municipal) contracts family farmers (individually or through farmers' associations or cooperatives) and purchases their products to supply public food stocks, which are directed to school feeding and communities in the state of food 
insecurity [46]. The programme has specific rules aimed at encouraging the participation of women in production and marketing. Contracts for the supply of food stocks and milk purchase require a minimum of $30 \%$ and $40 \%$ female farmers, respectively.

\section{The Study Area: Rain-Fed Family Farming Food System and the Fundo de Pasto Communities}

Our study case is situated in the municipality of Casa Nova, which is part of the semi-arid region of the state of Bahia (Brazil). High temperatures and drought are characteristic of this region, having an annual average rainfall and temperature of $800 \mathrm{~mm}$ and $25.4^{\circ} \mathrm{C}$, respectively [47]. The municipality of Casa Nova covers an area of $9.697 \mathrm{~km}^{2}$ and has a population of 64,940 inhabitants, of which about $42 \%$ of the individuals reside in rural areas [48]. Although the municipality of Casa Nova is close to the São Francisco River (as can be seen in Figure 2), the farmers do not use the water from the river for irrigation, due to the lack of appropriate infrastructure for this purpose.

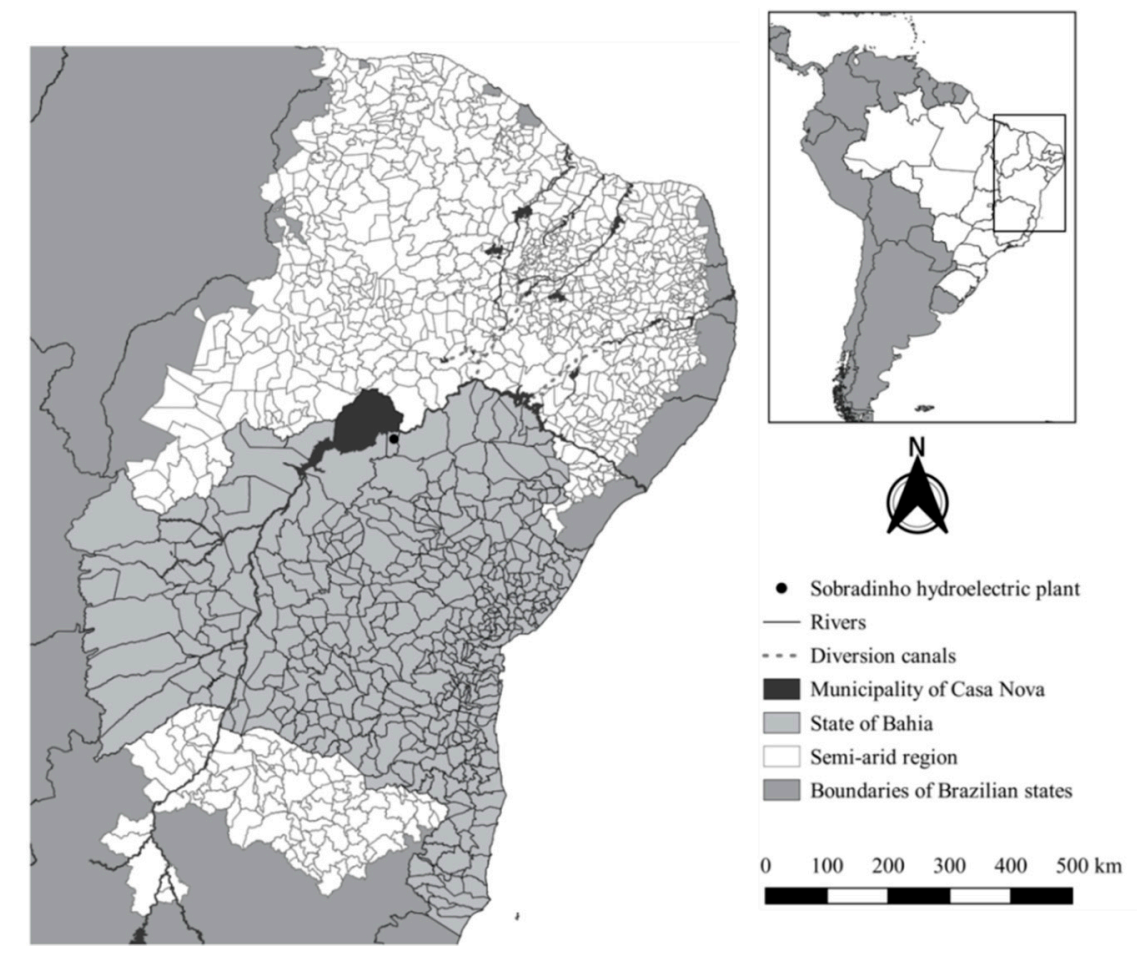

Figure 2. The location of the municipality of Casa Nova.

This study is part of a larger project, "Towards Food Sustainability: reshaping the coexistence of different food systems in South America and Africa", so we followed the project's criteria for the case study selection, which was based on (1) well-defined right to food (federal recognition of the right to food) for the country selection and (2) poverty and food insecurity.

In 2010, Constitutional Amendment 64 was implemented, making access to food a social right in Brazil (article $6^{\circ}$ of the Federal Constitution). We selected the state of Bahia because from its total population of approximately 14.8 million people, $43 \%$ live in poverty and $14 \%$ live in extreme poverty, levels above the national average of $25 \%$ and $8 \%$, respectively [49]. Of this number, $14 \%$ of citizens live in extreme poverty, and about $18 \%$ report living in food insecurity [49].

Communal land is the main feature of fundo de pasto communities and it is used for extensive animal rearing, being articulated with individual areas occupied by the families [50]. Families raise goats, sheep, free-range chickens and pigs and collect wild fruits and vegetables from communal areas while growing subsistence crops in individual properties to feed the family (trading the surplus) [51]. Food is often processed into cheese, juices, sweets, jams, cakes, cookies, tapioca, cassava pudding, etc. 
Three communities took part in this study: Melancia, Riacho Grande and Ladeira Grande. Table 1 shows the key characteristics of each community.

Table 1. Main features of the fundo de pasto communities included in this study.

\begin{tabular}{ccc}
\hline Community & Size of Land Occupied (Hectares) & Number of Families \\
\hline Melancia & 600 & 42 \\
Riacho Grande & 12,000 & 211 \\
Ladeira Grande & 2500 & 60 \\
\hline
\end{tabular}

The fundo de pasto communities were selected for this study based on the following criteria: (1) the relevance of the rain-fed food system to the socio-economic development of the semi-arid region; (2) good access of communities to food public policies; (3) we had previous contact with a community member, who helped us to access and interact with the families. Traditional communities usually are closed and do not allow the entry of outsiders.

Food production depends on seasonal rainfall in the rain-fed food system. The sales of fresh, stored or processed food follow two main methods: (1) independently, when the farmers are connected directly with the buyer by selling to the middleman or through the local market and (2) through associations and cooperatives in which the family's production is pooled together with the production of other families for a collective sale managed by the associations and cooperatives. This case is common when farmers participate in public food procurement programmes (PAA and PNAE). Work is predominantly performed by family members, having, occasionally, a maximum of two temporary workers over the year.

\section{Materials and Methods}

This paper draws on a qualitative inductive approach, and the research process was divided into 4 phases: bibliographic research, data collection, analysis of the effect of public policies and the evaluation of women's empowerment.

The bibliographic research included academic texts, books and reports that brought relevant information about the semi-arid region and its issues, in addition to theories and concepts that entailed the conceptual framework. Our search for scientific articles was conducted through the following platforms: Science Direct, Google Academic, Scielo and Scopus. The main keywords used in these searches were Brazilian semi-arid food systems, food sustainability, food security, women's empowerment, gender inequalities in rural contexts, intersectionality, social dynamics, food public policies and traditional family farmers. The topics of the books included women's empowerment, public policies for rural development in Brazil, social inclusion, public policies and democracy, fundo de pasto communities, rural development and gender. The reports that we used were mainly produced by FAO, United Nations Environment Programme (UNEP) and the Brazilian Ministries of Agrarian Development (Ministério do Desenvolvimento Agrário, MDA) and Social Development (Ministério do Desenvolvimento Social, MDS), which provided information on food sustainability, right to food, food systems, food security, women's empowerment and public policies for family farming implemented in Brazil. The bibliographic research can be fully appreciated in the references section.

The data were gathered through fieldwork coordinated by the first author, with assistance from the second author. The fieldwork took place in the municipalities of Petrolina (state of Pernambuco), Juazeiro and Casa Nova (state of Bahia) from October/2018 to January/2019. The fundo de pasto communities that participated in this study are located in Casa Nova. Petrolina and Juazeiro are neighboring municipalities to Casa Nova and also urban centers, concentrating NGOs, governmental institutions, universities, etc. Since we also interviewed members from these institutions, we included Petrolina and Juazeiro in the course of our fieldwork. 
Data collection entailed participatory observations of six focus groups with farmers from the Melancia, Riacho Grande and Ladeira Grande communities (each involving four to 12 farmers). The focus groups' themes and the number of participants in each of them can be seen in Table 2 .

Table 2. Focus groups' themes and numbers of participants.

\begin{tabular}{ccc}
\hline Focus Groups Themes & $\begin{array}{c}\text { Number of } \\
\text { Participants }\end{array}$ & $\begin{array}{c}\text { Participating } \\
\text { Communities }\end{array}$ \\
\hline Fundo de pasto communities (history of the communities) & 4 & $\begin{array}{c}\text { Riacho Grande, Ladeira } \\
\text { Grande and Melancia }\end{array}$ \\
\hline Food and water security, food sovereignty and food policies & 10 & $\begin{array}{c}\text { Riacho Grande, Ladeira } \\
\text { Grande and Melancia }\end{array}$ \\
\hline Rain-fed family farming food system and food policies & 12 & $\begin{array}{c}\text { Riacho Grande, Ladeira } \\
\text { Grande and Melancia }\end{array}$ \\
\hline $\begin{array}{c}\text { Income, struggle for land and political engagement } \\
\text { Productive groups, institutional market and women's roles at } \\
\text { the household and community levels * }\end{array}$ & 12 & $\begin{array}{c}\text { Riacho Grande, Ladeira } \\
\text { Grande and Melancia }\end{array}$ \\
\hline $\begin{array}{c}\text { Productive groups, institutional market and women's roles at } \\
\text { the household and community levels * }\end{array}$ & 12 & Ladeira Grande \\
\hline
\end{tabular}

${ }^{*}$ Groups composed exclusively of women.

Two of these focus groups brought together only women from the communities of Melancia and Ladeira Grande. The productive groups of women are linked, fundamentally, to the institutional markets (PAA and PNAE). Families from the Riacho Grande community are not part of these programmes, resisting dialogue with the government due to past violence involving disputes about accessing land. Usually, Riacho Grande families market their products directly with intermediaries and, less frequently, trade through the local market.

The focus groups gathered members from the three communities (Melancia, Ladeira Grande or Riacho Grande), except for the focus groups with women, since they were part of the same community. In addition, participants had to be willing to share experiences and information from a qualitative point of view with the researchers. We invited communities' farmers, local leaders and elderly people.

Our first contact with the communities was through focus groups. We aimed to have a broad picture of the participants' perceptions on the impacts of food public policies on the performance of the rain-fed food system and the conditions under which families and women make their living. For the first focus group, we defined the topic for discussions, which was "fundo de pasto communities-the history of the communities". The topics for the following meetings (see Table 2) were defined by participants during our first focus group. Additionally, on this occasion, researchers and participants built together the method to be followed throughout the debates, consisting of creating an arena for conversation in which everyone could express their opinion at any time, on the condition that, for each topic discussed, participants should mention whether there was any public policy related and how it affected the food system, families and women's conditions. Accordingly, the public policies considered in this study were selected by the participants. Additionally, the topics that they selected for the focus groups' debates became indicators, which can be seen below:

- Income stability and autonomy.

- Housework.

- Ensuring food and water security.

- Political engagement.

The indicator framework was used to assess, from the perspective of the participants, whether and how policies aiming at food family farms contributed to the improvement of women's conditions. 
The focus groups strategically occurred before the application of the questionnaires, so that we could use the information gathered in these collective reflections to design consistent questions. Questionnaires were applied to 54 families (18 families per community), and the families were selected based on the following criteria: (1) self-recognition as fundo de pasto members; (2) part of one of the communities selected for this study (Melancia, Ladeira Grande or Riacho Grande) and (3) the presence of an adult (regardless of gender) who was self-declared as the head of the family. Women were the head of the family in 37\% (20 families) of cases, being the main member responsible for the household income.

We also conducted semi-structured interviews with 11 representatives from institutionswhich were involved in the development and implementation of the programmes and policies and were part of organized social movements. The institutions that took part in this study were, as follows: Brazilian Agricultural Research Corporation (Empresa Brasileira de Pesquisa Agropecuária, EMBRAPA), Food and Nutrition Security National Council (Conselho Nacional de Segurança Alimentar e Nutricional, CONSEA), Regional Institute for Appropriate Small Farming and Animal Husbandry (Instituto Regional da Pequena Agropecuária Apropriada, IRPAA), Advisory Service for Rural People's Organizations (Serviço de Assessoria a Organizações Populares Rurais, SASOP), Pró-Semiárido, Pastoral Land Commission (Comissão Pastoral da Terra, CPT), Agrarian Development Coordination (Coordenação de Desenvolvimento Agrário, CDA) and Secretariat for the Promotion of Racial Equality (Secretaria de Promoção da Igualdade Racial do Governo do Estado da Bahia, Sepromi). We also interviewed two academics from the Bahia State University (Universidade do Estado da Bahia, UNEB) and Federal University of the Reconcavo of Bahia (Universidade Federal do Reconcavo da Bahia, UFRB).

During the fieldwork and interviews, we took notes and also made audio recordings. We used the content analysis to quantify the qualitative data [52] by identifying subjects and patterns from the dialogues and questionnaires through coding classification. We also used descriptive statistics to interpret the data.

Finally, we assessed women's empowerment at the personal level (individual) and the relational level (household and community levels). These scales of analysis were used since individual empowerment is strictly connected to relational changes [33]. This means that women must be willing to question the social structure that oppresses them and be aware of their role and importance to society (internal change) in order to change the environment and the relationships around them (relational change). The indicators that we used to measure women's empowerment were developed by Lombardini et al. in their study, "How To Guide To Measuring Women's Empowerment", published in 2007 [33]. The indicators can be seen in Table 3.

Table 3. Indicators applied for the women's empowerment assessment.

\begin{tabular}{|c|c|c|}
\hline Personal Level & \multicolumn{2}{|c|}{ Relational Level } \\
\hline Individual & Household & Community \\
\hline $\begin{array}{l}\text { Acknowledgment of women's } \\
\text { individual knowledge (e.g., agricultural } \\
\text { practices or milk production) }\end{array}$ & $\begin{array}{l}\text { Involvement in household } \\
\text { decision-making_expenditure, } \\
\text { investment and household } \\
\text { management decisions }\end{array}$ & $\begin{array}{l}\text { Participation in } \\
\text { community groups }\end{array}$ \\
\hline $\begin{array}{l}\text { Acknowledgment of women's role in } \\
\text { food and water security }\end{array}$ & Contribution to household income & Political participation \\
\hline \multirow[t]{3}{*}{ Personal and financial autonomy } & $\begin{array}{l}\text { Ability to reduce time devoted to } \\
\text { care responsibilities }\end{array}$ & Participation in public events \\
\hline & $\begin{array}{l}\text { Ability to redistribute burden of } \\
\text { care responsibilities }\end{array}$ & $\begin{array}{l}\text { Contribution to community } \\
\text { social needs }\end{array}$ \\
\hline & $\begin{array}{l}\text { Ability to have more time for } \\
\text { leisure and socializing }\end{array}$ & \\
\hline
\end{tabular}




\section{Results}

Public policies targeted at family farmers have the potential to transform the foundations of the food system [53]; they can also reduce gender asymmetries within the food system, strengthening the role of women [54]. In this section, we report whether and how public policies targeted at family farmers have contributed to women's empowerment from the perspective of the participants. We focus here on income stability and autonomy, women's dedication in guaranteeing household food and water security, political engagement, women's empowerment and their insertion within the food system.

\subsection{Policy Impacts on Women's Income Stability and Autonomy}

Relationships within the food system are marked by the sexual division of labor, which places women at the center of family relationship management by focusing on their roles as mothers, wives and housewives [55]. Thus, historically, many of the productive activities carried out by women have been considered an extension of domestic work [56]. Consequently, both domestic work and women's involvement in the food systems' activities is "invisibilized", not recognized and non-remunerated.

According to participants, before the public procurement programmes (PAA and PNAE), marketing involved selling the product to the middleman or through the local market. The income obtained through these options of commercialization fluctuated throughout the year, as sales depended on the purchasing power of the locals. However, most buyers were also residents of rural areas and made their living from agriculture, also having a fluctuating source of income. In addition, women were hardly involved in marketing. Their major contributions were limited to producing food within the property for household consumption, while the men's role was to raise animals and sell the products. The following statement is about productive groups of women and was given by a member from the NGO Regional Institute for Appropriate Small Farming and Animal Husbandry (Instituto Regional da Pequena Agropecuária Apropriada, IRPAA), which provides technical assistance to women in the communities.

"It is pretty clear that the purpose of the productive groups goes beyond the income generation for women or their insertion in the labor market. The groups are strategic for linking ecological awareness and preservation of the Caatinga biome through agro-ecological techniques to grow food and improvement of the socio-economic conditions of women, which turns into food security and improvement of the quality of life of the families"(Informant 1; member of the NGO IRPAA).

The public procurement programmes created an alternative market for family farming products and stimulated the formation of organized productive groups. Through productive groups, participants reported that women became more involved in trading activities. We had two focus groups composed only of women, who were involved with productive groups, being part of PAA and PNAE. One group was part of the community of Ladeira Grande and another was related to the community of Melancia.

The group of women from the community of Ladeira Grande has been supplying products to the PAA for 13 years, providing fruits and vegetables such as watermelon, pumpkin, potatoes, cassava, cabbage, umbu, guava and fruit jellies. Overall, women grow food in the individual family lot and pool their products with the production of other women for collective sales. The contract with PNAE is more recent (five years) and women provide cake, tapioca, cassava pudding and cookies, which are used for school meals. According to the participants, both programmes were essential for providing a reliable income for women in the group. They emphasized that the long-term contracts enabled them to have a monthly income, which was fundamental in terms of household financial planning and stability. One of the central issues concerns economic autonomy since, out of the 12 women who participated in the focus group, seven stated that the income obtained constituted more than half of the monthly family income.

The group of women from Melancia has been supplying products to PAA for 10 years and to PNAE for 7 years, also providing vegetables and fruits. They also stated that the income obtained by participating in the programmes guaranteed them financial autonomy from their husbands. Out of the 12 participants, 10 women reported that their income covers more than half of the monthly 
family income. Scheme 1 compares data from Ladeira Grande and Melancia concerning women's contributions to the family's income.

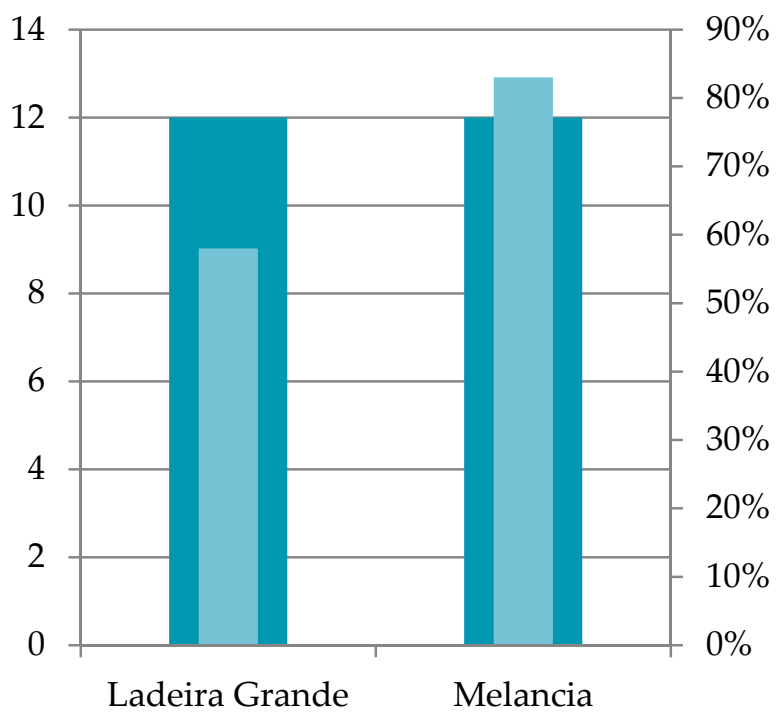

Number of participants (focus groups)

Percentage of participants, whose income is more than half of the monthly family income

Scheme 1. Women's contributions to the family's income.

In addition to income stability and autonomy, both programmes contributed to women's sense of collectivity. By working together, they multiply production without increasing costs, through economies of scale. Moreover, by participating in these collective organizations, farmers have more opportunities to obtain agricultural inputs that they often could not have if only performing individually. The statement below was shared with us in the focus group of women from the community of Melancia and it concerns the role of PAA and PNAE in opening up space for women's involvement in the market.

"The programmes [PAA and PNAE] were important because, first of all, we women were not involved in the marketing part. That was men's work, wasn't it? And secondly, selling fruits and vegetables as a group is better than as an individual. Before, when our families sold at the local market, we couldn't sell all the stock, so that the food spoiled and ruined. Today we put together all the food we grow on our farms and sell to the government at once. Food doesn't spoil anymore and it's also cheaper for us" (Informant 2; member of Melancia's community).

Both groups benefited from the technical assistance provided by local NGOs, through the Programme for the Productive Organization of Rural Women (Programa Organização Produtiva de Mulheres Rurais, POPMR). Technical assistance is arranged in three ways: (1) assisting farmers to start productive groups, (2) helping farmers to deal with bureaucracies and application to the programmes and (3) assisting farmers in the food growing process.

NGOs hold workshops to qualify women, encouraging them to manage their productive groups. They offer support to account for costs, to save inputs throughout the production process, organize the logistics, etc. In addition, NGOs offer women training oriented in agro-ecological practices (e.g., avoiding the use of chemical fertilizers) to grow food for household consumption and trade. Overall, women agreed that technical assistance helped them at the beginning of their productive group activities, because they did not know how to deal with trade and negotiations in this regard, either in terms of food stock control, cash flow or further bureaucracies, which are essential for participation in institutional markets.

One of the problems reported in the focus groups of women was the difficult access to the Declaration of Aptitude to PRONAF-National Programme for Strengthening Family Farming (DAP), which is a document required to participate in institutional market programmes and to have access to 
rural credit. DAP consists of a national administrative register through which the federal government gives legal recognition to the family unit. The difficulty for women is that DAP is conferred only to one member of the family and, in the context of gender inequalities, the result is that men represent the families in most cases. In the productive groups of women, none had access to DAP.

To trade their products through the institutional market, women who are part of the productive groups use the DAP that belongs to community associations. Women from the Ladeira Grande community productive group affirmed that the fact that they do not hold the document does not affect the final income they receive from sales, which is shared equally by all women and corresponds to an annual amount of R\$5500 per person (approximately US\$960.00). However, they stated that they do not like to rely on the president of the association (a man) to make decisions regarding their group since he is not directly involved with the group's activities and is not aware of the group's dynamics. There are constant conflicts, as the president often makes suggestions out of context, but because he occupies a higher hierarchical position, he has more power in decision-making.

According to the participants' perspective, public procurement programmes opened up space for women's involvement in productive groups, providing them with a stable income and financial autonomy from their husbands. The technical assistance also helped women to better organize trade and the bureaucratic units' procedures, by providing them with specialized knowledge. However, the difficulty in accessing the DAP documentation is still limited among women from the communities.

\subsection{Policy Impacts on Women's Roles in Food and Water Security and Housework Conditions}

There are studies about the role played by women in ensuring household food and water security [57-60], highlighting women's influence over the subsistence agriculture and unpaid water collection. In addition to being involved in food growing, women are responsible for domestic work, which involves the care of children and housework that are not recognized as work but as an obligation given by their condition as wives and mothers [61].

Participants in the focus groups pointed out the importance of technical assistance for the improvement of women's food growing labor. They also highlighted the role played by the cisterns in freeing women from daily water collection. Finally, they understood the Bolsa Familia as an instrument created to reduce gender asymmetries.

The Programme for the Productive Organization of Rural Women (POPMR) encourages women involved in the small-scale production of food for household consumption to adopt the principles of agro-ecology. According to the participants, one of the projects that stands out the most is the "productive yards" (quintais produtivos), in which women are instructed to use internal inputs and produce food with high nutritional value without pesticides or chemical fertilizers. In all the family lots we visited, we observed the existence of a space measuring approximately three thousand square meters, where a variety of vegetables and fruits is grown together with animals. Thus, the vegetables are fertilized with the animal dung (goats), chickens receive part of the corn planted in the farm, and, in cases where the family raises pigs, they receive part of the domestic food and crop waste. Farmers affirmed that this is an old technique applied among the community members, but it has been improved with the help of technical assistance.

Many women in focus groups reported that, before the technical assistance, they used the agro-ecological techniques intuitively, but now they understand the benefits of these practices and how they work to maintain the resilient environment. Women also declared that technical assistance notably helped them to increase food production, leading the family to consume more food grown on-farm. They also pointed out that they started to better organize the time spent on food growing activities, leaving time for other activities such as children's care, productive group activities and domestic work. They also stated that the number of accidents resulting from the improper handling of tools and equipment has reduced. When we asked women to what extent their work was important for the family's food subsistence, participants from the female focus groups declared that most of the times, 
women and girls are the only members of the family to be involved in food growing, demonstrating that they were aware of the relevance of their work for household food consumption.

The dialogue below is about women's assessment of the technical assistance, taken from the focus group on food and water security.

"Informant 3: technical assistance showed us how to make our system more resilient.

Informant 4: we already knew all those techniques, but they showed us why they were important not only for resilience but for growing more nutritious food.

Informant 3: we now consume more of the vegetables we grow in our farm, because the quality is much better than the ones we find in the supermarket or in the local market. We never know if they use fertilizers or agrochemicals" (Informants 3 and 4, members of Melancia and Riacho Grande communities).

Linked to the technical assistance policy, the cisterns also helped to increase on-farm food production, in addition to boosting food variety. Most of the fruits previously consumed by families were collected from wild plants, but after the cisterns were implemented, some of these wild fruits started to be cultivated on the farms, such as seriguela, guava, starfruit, cajá and cashew. Through questionnaires, all participants declared that cisterns helped to increase the diversification of on-farm food production; $82 \%$ affirmed that the food diversification improved the family's feeding and food security and $93 \%$ stated that they increased their consumption of fruits and vegetables.

According to participants, the combination of measures contributed to the household reduction of food insecurity, especially during periods of drought. All 54 families received at least one cistern from the P1MC programme, which allowed the collection, storage and consumption of rainwater. Before the cisterns, people collected improper water from dams, located far from the communities.

Our study found out that, historically, women and girls were in charge of ensuring household water security in the semi-arid region. As follows, we present a statement shared in a focus group in which a female participant reported the condition before and after the cisterns.

"Before the cisterns, we took water from the dams, but the water was not always available. In the winter [rainy season, from January to April], usually, we could find water, but when the drought began, the water got more turbid and muddy. Also, several animals consumed the same water as we. I had to boil the water to offer to my family, but still, my kids had diarrhea and vomiting. Now everything is better. When I wake up, I prepare breakfast and then go to the field to help my colleague to peel the cassava she cultivates. I have more time to dedicate myself to work and earn a little bit of money" (Informant 5, member of Ladeira Grande community).

The cisterns provided considerable time savings for women since it was no longer necessary for them to walk long distances for water. According to participants in one of the focus groups, the time saved allowed women to engage in household activities, especially the education and care of children, housework and farming. The standard responses about what they do in their additional time led us to deduce that free time for these women does not translate into leisure time. On the contrary, this means more time to spend working. Women also informed us that now they invest more time in productive group activities, being involved more actively in the units, associations and cooperatives. Participants also reported an increase in female participation in events, conferences and workshops related to the struggle for land. The cisterns contributed significantly to women's autonomy concerning the use of their own time.

Bolsa Familia, which consists of a financial support policy whose conditionalities include keeping children in school and ensuring the health of pregnant women and children, was mentioned as being relevant for reducing gender asymmetries. This is because the financial support is given by priority to 
women, because the government assumes that they use the money for the benefit of the whole family, avoiding satisfying individual needs [62]. Based on data from questionnaires, approximately $72 \%$ of the families benefited from Bolsa Familia, and from these 39 families, women were the family members that received the amount in $91 \%$ of cases. Participants benefiting from the programme agreed that the monthly financial support increased financial security, even though they recognize that the amount is very low and not enough for the family's needs.

The regularity of the cash transfer was pointed out as the greatest strength of Bolsa Familia, which is very important for these families since the income from agricultural activities fluctuates significantly throughout the year. The amount that each family receives ranges from R $\$ 41$ to $R \$ 372$ (US\$ 7.16 and US\$ 64.97, respectively), varying according to the family's financial situation (extremely poor or poor) and the number and age of the children [63]. All respondents benefiting from the Bolsa Familia stated that their children were enrolled in schools within the communities. Through questionnaire interviews, 18 families declared that they had children under the age of seven years old and all of them had their children's vaccinations under control. While six families stated that they accessed the vaccines at the local public clinic, the remaining 12 had to travel for vaccinations at the public clinics located in the urban area of Casa Nova, which is $40 \mathrm{~km}$ away from the communities. Only one of the interviewees was pregnant and said she had already scheduled the first consultation for prenatal care since, at the time of the interview, she was still in the early pregnancy stage, and 15 participants stated that they had already received prenatal care.

Despite being historical breakthroughs, these public policies also present contradictions. The main flaw related to the technical assistance is that the support for food growing is offered exclusively to women. Consequently, it centralizes all work on women and removes from men the responsibility of ensuring family food security. Additionally, by not including men, the programme reinforces the existing sexual household division of labor, which, in the communities, takes the form of a hierarchy. The importance of work varies from the least to the most valued, in the following order: housework, growing food for family consumption and livestock for marketing. While housework, children's care and food growing are women' tasks, animal husbandry and trade are tasks carried out by men.

The differentiation in the value of household work makes women's work invisible and consequently not recognized among the remaining members of the family. In a focus group that involved only women from the community of Ladeira Grande, participants felt encouraged to complain about the lack of recognition of their work, stating that they work just as much as their husbands and brothers, but the financial return is under the dominance of the male figure. The non-remuneration of women means that their work is not recognized as such. Despite the invisibility of women's work, they represent $41 \%$ of the workforce on the farms where the questionnaire was applied. They also reported that, since they do not receive part of the profit from the farm activities, they are not invited to participate in the decisions made among the family members regarding the use of money. The exception is when they earn their own money from off-farm jobs. In such cases, they decide together with their partners and other adult members who live in the farm on how to manage the amount. The dialogue below was captured in a focus group which brought together women from the Ladeira Grande community.

"Informant 6: in my house, women always worked as farmers harvesting, planting and taking care of the animals. However, my mother and my grandmother never earned any money from these activities. It was much more a matter of planting food to eat.

Informant 7: my father never consulted my mother to decide what to buy for the farm. He was involved in selling the products. He decided how to spend the money we got.

Researcher: how about now that you work in the productive group and earn money ... do you participate in decisions at home?

Informant 8: as the money is mine, I have more rights to decide, right? 
Informant 7: people here in the group usually decide together with their husbands what to do with the money, but when the money is not ours they [the husbands] spend the money the way they think it's better" (Informants 6, 7 and 8, members of the Ladeira Grande community).

Regarding Bolsa Família, participants indicated that because women benefit, in most cases, from the programme's financial support, it has an important role in reducing gender inequalities. This perspective highlights only the reduction of economic differences between men and women within the household context. However, it does not consider that the fulfilment of the conditionalities related to education and children's healthcare are tasks assigned to women. According to data from questionnaires, in $89 \%$ of cases, women are responsible for reporting to the government the fulfilment of the conditionalities, monitoring children's attendance to school and managing their families' healthcare.

Therefore, Bolsa Familia makes instrumental use of women by attributing to them the responsibility of controlling the policy implementation. The programme does not include women in the circle of changes to which it is proposed. According to Sylvia Chant in her paper on "Feminization of Anti-Poverty" programmes, instead of creating policies targeted at women, the government puts women to work for the policies [64].

\subsection{Women's Political Engagement and Social Dynamics}

The 2000s were characterized by the emergence of comprehensive socio-economic and environmental food policies targeted at rural workers in Brazil, which triggered a notable increase in the participation of women in spaces predominantly occupied by men, such as the market, NGOs, associations and cooperatives.

During an interview with the former president of the Food and Nutrition Security National Council (Conselho Nacional de Segurança Alimentar e Nutricional, CONSEA) from the municipality of Juazeiro (Bahia), she stated that rural women became much more involved in the communities' socio-economic and political issues. According to her comments made a few years ago, it was very difficult to find women integrated and working in cooperatives and associations of rural producers. As part of a traditional rural community, she noticed that, in recent years, further women around her felt more motivated to engage in political and social movements. Thus, they force women's participation in environments historically occupied by men where, consequently, there prevails a discourse that does not represent them.

All families that answered the questionnaire participate in associations of small rural producers and $66 \%$ are integrated into cooperatives. The family unit does not say much about the effective participation of women in institutional spaces, but some women that we interviewed occupy important positions in these institutions. Both the Riacho Grande fundo de pasto association and the union of fundo de pasto associations (an institution that represents all the fundo de pasto associations in the state of Bahia) are managed by the same woman. The Agricultural and Family Cooperative of Casa Nova has six women in its administrative staff (which has a total of 11 people). Women are also members of NGOs such as the Regional Institute for Appropriate Small Farming and Animal Husbandry (Instituto Regional da Pequena Agropecuária Apropriada, IRPAA) and Advisory Service for Rural People's Organizations (Serviço de Assessoria a Organizações Populares Rurais, SASOP). Nine women who participated in the focus groups were considered community leaders for their active involvement in forums representing the demands of the communities, for having applied for political posts, for being directly involved in the struggle for land, for occupying or for having held the position of president of associations, etc.

The presence of women in such spaces is fundamental, as society continually needs to seek gender equality as an ethical and essential commitment to freedom of expression and democracy. Additionally, the participation of historically marginalized groups in decision-making opens up space for new discourses and demands from groups that were previously "invisible". The CONSEA former president was incisive in saying that, by participating in the institutions, women do not seek to repress or silence existing agendas. Indeed, they seek the coexistence of ideas: 
"When women occupy these spaces, they do not want to silence anyone, nor prevent men from taking a position about feminism. We just want to exist in certain spaces that have been denied us, historically, and to coexist with different agendas. Men can talk about women's demands, but it is important that they are aware about their privileged social position. The first step toward a more equal society, in terms of gender, consists in men acknowledging their privileges and taking responsibility for the social structure that subordinates women" (Informant 9, former president of CONSEA).

In this context, as women increasingly occupy positions in institutions, they expand the possibility of dialogue with the government, since as an individual, this possibility becomes more remote. Women from fundo de pasto communities are exposed to systematic discriminations and oppressions, which combine gender, social class, way of life, rural situation, geographic location and so on, creating inequalities that determine their marginalization in the social structure. Intersectionality [65] reveals the multiplicity of systematic oppression imposed on women from fundo de pasto communities, being a powerful instrument to identify the roots of socio-economic imbalances.

Political engagement emerges from a combination of individual characteristics, social group membership and political processes. It also entails how public policies are perceived by the public and how they are translated into participation in civil society in their design, monitoring and improvement $[66,67]$. Based on participants' reports, the combination of public policies targeted at family farmers culminated in women's political engagement, providing visibility to issues of a social group that has always been neglected in this sphere of power.

\subsection{Are Public Policies a Pathway to Women's Empowerment?}

In this section, we evaluate whether and how these food public policies were translated into women's empowerment. For this purpose, we assessed the information that was shared with us through focus groups, questionnaires and semi-structured interviews, considering two levels of analysis of empowerment: personal (individual) and relational (household and community). The personal level corresponds to the change that takes place within the person, concerning how women perceive their role and importance to society [33]. According to the same author, the relational level refers to the changes occurring in the power dynamics involving women, household and community members. For each level of analysis, we identified whether and how the participants addressed the indicators presented in Table 3. Table 4 shows how participants perceived women's empowerment at the personal and relational levels (household and community).

At the personal level, women are fully aware of their importance in ensuring household food and water security. At several points during the debates that took place in the focus groups, women stated that they are the only ones working in food growing for family consumption, while their partners are dedicated to raising animals for trade and off-farm jobs. Despite the lack of recognition from other family members, women knew that their work was fundamental. In addition, women felt much more empowered after the implementation of the cisterns, which gave them the personal autonomy to decide how to spend their time, since long walks in search of water were no longer needed. Not only women but the vast majority of the participants recognized the work of women in the communities in guaranteeing household water security. Finally, women stated that PAA and PNAE were fundamental for them to achieve financial autonomy, but the difficulties of accessing the DAP (necessary documentation for independent participation in institutional markets and the acquisition of credit) make them depend on third party documentation. In this sense, the autonomy of decisions as a group of farmers is compromised. 
Table 4. Participants perceptions of women's empowerment on the personal and relational levels.

\begin{tabular}{|c|c|}
\hline $\begin{array}{l}\text { Topics Observed in Speeches and } \\
\text { Perspectives of Participants }\end{array}$ & Personal Level \\
\hline $\begin{array}{l}\text { Acknowledgment of women's individual } \\
\text { knowledge (e.g., agricultural practices or } \\
\text { milk production) }\end{array}$ & Participants value women's knowledge of agricultural practices \\
\hline $\begin{array}{l}\text { Acknowledgment of women's role in food } \\
\text { and water security }\end{array}$ & $\begin{array}{l}\text { Women are aware of their importance for ensuring food and } \\
\text { water security, but their partners do not recognize their work }\end{array}$ \\
\hline \multirow[t]{2}{*}{ Women's personal and financial autonomy } & $\begin{array}{l}\text { Women have achieved financial stability through the } \\
\text { institutional market, but they still have difficulty achieving } \\
\text { autonomy when it comes to productive groups }\end{array}$ \\
\hline & Relational Level (Household) \\
\hline $\begin{array}{c}\text { Involvement in household } \\
\text { decision-making-expenditure, } \\
\text { investment and household management } \\
\text { decisions }\end{array}$ & Not reached \\
\hline Contribution to household income & Women managed to contribute to household income \\
\hline $\begin{array}{l}\text { Ability to reduce time devoted to care } \\
\text { responsibilities }\end{array}$ & Not reached \\
\hline $\begin{array}{l}\text { Ability to redistribute burden of care } \\
\text { responsibilities }\end{array}$ & Not reached \\
\hline \multirow[t]{2}{*}{$\begin{array}{l}\text { Ability to have more time for leisure and } \\
\text { socializing }\end{array}$} & Not reached \\
\hline & Relational Level (Community) \\
\hline Participation in community groups & $\begin{array}{l}\text { Women participate in productive groups, which provide food for } \\
\text { food procurement programmes }\end{array}$ \\
\hline Political participation & $\begin{array}{l}\text { Women hold positions in institutions and expand contact with } \\
\text { government agencies }\end{array}$ \\
\hline Participation in public events & Women felt more motivated to attend lectures, workshops, etc. \\
\hline Contribution to community social needs & Women became more directly involved in the struggle for land \\
\hline
\end{tabular}

At the relational level, in the household context, women hardly progressed in terms of empowerment. Although some women declared that stability and economic autonomy allowed them to contribute more than half of the monthly family income, it is only in these situations that they gain voice and decision-making power to intervene or opine on household expenditure. The financial autonomy of rural women may contribute to the reduction of rural poverty, but it does not necessarily increase women's decision-making power, nor does it break with the pattern of the sexual division of labor. Housework is performed exclusively by women, demonstrating the difficulty of women in sharing such tasks with their partners. Women's roles as housewives are reinforced by the Bolsa Familia programme, which grants the financial support to them by priority. Since they receive the grant, they are also responsible for monitoring the education and healthcare of their children and family. The additional time gained by women after the arrival of cisterns was predominantly used for work, which varies between housework, productive groups and involvement in social movements. There was no mention of leisure or investment of time for study.

At the community level, women performed well towards empowerment, participating in productive groups within the community in addition to increasingly occupying positions in institutions such as NGOs, associations and cooperatives. By being present in these institutions, women expanded the possibility of dialoguing with government sectors, making it possible to give visibility to their specific demands. In addition, women reported that they began to be involved in the community's 
interests, such as the land struggle, being more present in spaces where the topic is discussed (workshops, seminars and lectures).

\section{Discussion and Conclusions}

Historically, the recognition of women's productive potential in rural areas has been undermined by the complex social structure, despite their proven importance for food security [1]. The set of systematic oppressions make women's labor invisible, since the activities that they usually are involved with are often associated with unpaid domestic work, such as caring for family health, preparing food and cleaning the house, in addition to food growing for domestic consumption and the rearing of small animals [61]. In Brazil, the 1980s were marked by social movements, with strong participation of family farmers, who demanded social rights, better working conditions and the reduction of gender inequalities that placed women in positions of subalternity [4]. These social mobilizations put pressure on changes in the political context, culminating in the inclusion of family farmers as part of the agrarian development process [6]. The change in the political perspective led to the elaboration of a specific agenda for rural women during the Brazilian former president Luiz Inácio Lula da Silva's presidency (2003-2011). Since then, a set of measures has been developed, aiming to meet the historical demands of this social group, such as access to rural credit and financial support for the poorest, the expansion of technical assistance and the diffusion of contextualized technologies to socio-economic and ecological conditions in which family farmers live.

We evaluated how public policies targeted at family farmers affected socio-economic and political women's empowerment. For this purpose, we applied indicators such as income condition, housework, political engagement and work ensuring food and water security, seeking to understand how transformations in these sectors would unfold in women's empowerment at the personal and relational levels (household and community). The results show that local farmers perceived that the integrated set of policies that link needs to reduce food insecurity, the insertion of farmers in the market and the dissemination of technology, knowledge and financial support had positive effects on promoting women's better socio-economic conditions of living from the rural economy. Despite these advances, in the household context, women still have to deal with the sexual division of labor and the invisibility of the work performed by them.

Positive assessments were made by farmers regarding access to water through the cisterns, which, besides improving families' water security, promoted women's self-autonomy to decide how to spend their time since they no longer needed to walk long distances for water. The Programme for the Productive Organization of Rural Women (POPMR), which offers technical assistance to women, has instructed women and encouraged them to form productive groups to access institutional markets. The programme also assisted women in food production through agro-ecological techniques, which improved household food security, since women are the main members who are responsible for growing food for family consumption. The same positive view entails the well-functioning public procurement that enabled women's financial stability by facilitating their access to markets. This conjuncture of factors encouraged women to become involved with institutions such as cooperatives, associations and NGOs, occupying spaces previously occupied by men. Through women's greater political engagement, their specific agenda gained visibility, constituting an important step towards social dynamics.

Public policies are an expression of popular claims; however, they also carry contradictions [68]. The difficult approach to the necessary documentation that allows them access to institutional markets and rural credit (DAP) undermines the autonomy of women as a group since they depend on a third party for these purposes. Both technical assistance programmes (Programme for the Productive Organization of Rural Women) and financial support (Bolsa Família) reinforce the sexual division of labor in the household context by centralizing responsibilities in the figure of women.

Women's awareness of their importance for food security is a positive demonstration of empowerment, as well as their political and institutional involvement and engagement. However, policies have not been able to break with the sexual division of labor at the household level. Through 
observations and interviews with participants, we understood that the differences within the household go beyond the gender labor division. It takes the form of a hierarchy which depreciates the work carried out by women (housework and food production for household consumption) and values the work developed by men (production of animals for trade). Although women and girls work in the farm, carrying out various activities, their effort is not considered work [69].

Our assessment of the public food policies' impacts on the socio-economic and political women's empowerment allows us to conclude that public policies had both inclusive and contradictory effects since they simultaneously empowered women and reinforced the sexual division of labor. In an attempt to contribute to debates about public food policies, we have summarized below a series of recommendations for further academic discussion that could be applied to improve programmes.

One of the major problems identified in all the policies selected for this study is their broad approach, not attending the specific needs of the heterogeneous and socially diverse categories of family farmers in Brazil. Therefore, public policies should internalize complex overlapping features to be more efficient and include as many farmers as possible, by taking into account gender, socio-economic conditions and geographic location.

Looking more deeply into each policy, we understand that Bolsa Familia could offer additional financial support to encourage women to keep studying. The Programme for the Productive Organization of Rural Women (technical assistance) could create forms to include men in the activities of food production for family consumption, decentralizing household tasks. Finally, regional categories of the DAP document should be created to include marginalized women.

Author Contributions: Conceptualization, E.A.F.B. and S.R.; methodology, E.A.F.B. and S.R.; data collection, E.A.F.B. and T.d.R.S.; formal analysis, E.A.F.B.; writing-original draft preparation, E.A.F.B.; supervision, S.R. All authors have read and agreed to the published version of the manuscript.

Funding: The first author received financial support from the Swiss Government Excellence Scholarships for Foreign Scholars and Artists: ESKAS 2017.0764. The first author also was granted financial support from the Leading House for the Latin American Region for the fieldwork. The co-authors received support from the Swiss National Science Foundation (SNSF) through the Swiss r4d programme, grant number: SNSF 400540-152033. We also benefited from the Bern University Research Foundation.

Acknowledgments: We are very grateful to the fundo de pasto communities that took part in this study and the local leaders who established the connection between us and the family farmers.

Conflicts of Interest: The authors declare no conflict of interest.

Ethics Statement: Verbal informed consent was obtained from all the sampled populations before the study. The participants were informed that their contribution was anonymized and would only be used for research purposes. Ethical approval was not sought for the present study because it is not required, as per the University of Bern guidelines and applicable national regulations.

\section{References}

1. FAO. Empowering Rural Women, Powering Agriculture; Food \& Agriculture Organization: Rome, Italy, 2018.

2. Siliprandi, E. Mulheres Agricultoras e a Construção Dos Movimentos Agroecológicos No Brasil. In Mulheres Camponesas: Trabalho Produtivo e Engajamentos Politicos; Neves, D.P., Medeiros, L.S., Eds.; Alternativa: Niteroi, Brazil, 2013; pp. 329-343.

3. Deere, C.D.; Leo, M. O Empoderamento Da Mulher; UFRGS: Porto Alegre, Brazil, 2002.

4. Heredia, B.M.A.; Cintrão, R.P. Gênero e Acesso a Políticas Públicas No Meio Rural Brasileiro. Rev. Nera 2012, 9, 1-28.

5. Santos, F.P.D. Coalizões de Interesses e a Configuração Política Da Agricultura Familiar No Brasil. Ph.D. Thesis, Fundação Getúlio Vargas, Rio de Janeiro, Brazil, 25 February 2011.

6. Grisa, C.; Schneider, S. Três gerações de políticas públicas para a agricultura familiar e formas de interação entre sociedade e Estado no Brasil. In Políticas Públicas de Desenvolvimento Rural no Brasil Catia and Schneider, Sergio; UFRGS: Porto Alegre, Brazil, 2015; pp. 19-50.

7. Hernández, C.O. Política de Crédito Rural com Perspectiva de Gênero: Um meio de "Empoderamento" das Mulheres Rurais? Ph.D. Thesis, Universidade Federal do Rio Grande do, Porto Alegre, Brazil, 16 March 2009. 
8. Desa, U.N. General Assembly Resolution, Transforming Our World: The 2030 Agenda for Sustainable Development; United Nations: New York, NY, USA, 2015.

9. Abers, R.N.; Silva, M.K.; Tatagiba, L. Movimentos sociais e políticas públicas: Repensando atores e oportunidades políticas. Lua Nova 2018, 105, 15-46. [CrossRef]

10. Perrucci, R.; Perrucci, C. The Good Society: Core Social Values, Social Norms, and Public Policy. Sociol. Forum 2014, 29, 245-258. [CrossRef]

11. Logeswari, S.; Thiruchenduran, S. Thiruchenduran. Empowerment of Women Farmers for Agricultural Development. Imp. J. Interdiscip. Res. 2016, 2, 991-992.

12. Bayeh, E. The role of empowering women and achieving gender equality to the sustainable development of Ethiopia. Pac. Sci. Rev. B Humanit. Soc. Sci. 2016, 2, 37-42. [CrossRef]

13. Van den Bold, M.; Quisumbing, A.R.; Gillespie, S. Women's Empowerment and Nutrition: An Evidence Review. IFPRI Discussion Paper (Electronic Journal). 1 September. Available online: https://ssrn.com/ abstract=2343160; http://dx.doi.org/10.2139/ssrn.2343160 (accessed on 15 February 2020).

14. Jones, R.; Haardörfer, R.; Ramakrishnan, U.; Yount, K.M.; Miedema, S.; Girard, A.W. Women's empowerment and child nutrition: The role of intrinsic agency. SSM Popul. Health 2019, 9, 1-11. [CrossRef] [PubMed]

15. FAO. Good Practices for Integrating Gender Equality and Women's Empowerment in Climate-Smart Agriculture Programmes; Food \& Agriculture Organization: Atlanta, GA, USA, 2019.

16. FAO. Training Guide: Gender and Climate Change Research in Agriculture and Food Security for Rural Development; Food and Agriculture Organization: Rome, Italy, 2012.

17. Spanevello, R.M.; Matte, A.; Boscardin, M. Crédito rural na perspectiva das mulheres trabalhadoras rurais da agricultura familiar: Uma análise do Programa Nacional de Fortalecimento da Agricultura Familiar (PRONAF). Polis. Rev. Latinoam. 2016, 44, 1-44. [CrossRef]

18. Staduto, J.A.R.; Souza, M.D.; Nascimento, C.A. Desenvolvimento Rural e Gênero: Abordagens Analíticas, Estratégias e Políticas Públicas; UFRGS: Porto Alegre, Brazil, 2015; pp. 69-95.

19. Becher, C.; Klanovicz, J. Mulheres Camponesas e os Desafios do Acesso às Políticas Públicas para Igualdade de Gênero. Rev. Lat. Am. Geogr. Genero 2016, 7, 159-177. [CrossRef]

20. Mulgan, G. Social Innovation: What Is It, Why It Matters, How It Can Be Accelerated; Basingstoke Press: London, UK, 2007.

21. Phills, J.A.; Deiglmeier, K.; Miller, D.T. Rediscovering Social Innovation. Stanf. Soc. Innov. Rev. 2008, 6, $34-43$.

22. Bernstein, H. And Now Who Plans Its Future? Land in South Africa after Apartheid. In When History Accelerates: Essays on Rapid Social Change, Complexity and Creativity; Hann, C., Ed.; Athlone Press: London, UK, 1994; pp. 161-187.

23. Giddens, A. A Constituição da Sociedade; Editora Martins Fontes: São Paulo, Brazil, 1989.

24. Farmer, T.; Reinke, W.M.; Brooks, D.S. Managing Classrooms and Challenging Behavior: Theoretical Considerations and Critical Issues. J. Emot. Behav. Disord. 2014, 22, 67-73. [CrossRef]

25. Müller, C.; Zurbriggen, C. An Overview of Classroom Composition Research on Social-emotional Outcomes-Introduction to the Special issue. J. Cogn. Educ. Psychol. 2016, 15, 163-184. [CrossRef]

26. Atkinson, A.B. Social exclusion, poverty and unemployment. In Exclusion Employment and Opportunity; Atkinson, A.B., John, H., Eds.; London School of Economics: London, UK, 1998; pp. 9-24.

27. Social Exclusion Unit. Social Exclusion Unit: Purpose, Work Priorities and Working Methods; The Stationery Office: London, UK, 1997.

28. Burchardt, T.; Le Grand, J.; Piachaud, D. Degrees of exclusion: Developing a dynamic, multidimensional measure. In Understanding Social Exclusion; Hills, J., Le Grand, J., Piachaud, D., Eds.; Oxford University Press: Oxford, UK, 2002; pp. 30-43.

29. Levitas, R.; Pantazis, C.; Fahmy, E.; Gordon, D.; Lloyd, E.; Patsios, D. The Multi-Dimensional Analysis of Social Exclusion; University of Bristol: Bristol, UK, 2007.

30. Abramo, L.; Cecchini, S.; Morales, B. Social Programs, Poverty Eradication and Labour Inclusion: Lessons from Latin America and the Caribbean; United Nations: Santiago, Chili, 2019.

31. Sardenberg, C.M. Liberal vs. Liberating Empowerment: A Latin American Feminist Perspective on Conceptualising Women's Empowerment 1. IDS Bull. 2008, 39, 18-27. [CrossRef]

32. VeneKlaseny, L.; Miller, V. A New Weave of Power, People and Politics: The Action Guide for Advocacy and Citizen Participation; World Neighbors: Oklahoma City, OK, USA, 2002. 
33. Lombardini, S.; Bowman, K.; Garwood, R. A 'How to Guide to Measuring Women's Empowerment: Sharing Experience from Oxfam's Impact Evaluations; Oxfam: Oxford, UK, 2017.

34. Sraboni, E.; Malapit, H.J.R.; Quisumbing, A.R.; Ahmed, A.U. Women's empowerment in agriculture: What role for food security in Bangladesh? World Dev. 2014, 61, 11-52. [CrossRef]

35. Harper, S.; Zeller, D.; Hauzer, M.; Pauly, D.; Sumaila, U.R. Women and fisheries: Contribution to food security and local economies. Mar. Policy 2013, 39, 56-63. [CrossRef]

36. FAO. Rome Declaration on World Food Security and World Food Summit Plan of Action; Food \& Agriculture Organization: Rome, Italy, 1996.

37. Dury, S.; Bendjebbar, P.; Hainzelin, É.; Giordano, T.; Bricas, N. Food Systems at Risk: New Trends and Challenges; FAO: Rome, Italy; CIRAD: Montpellier, France; European Commission: Brussels, Belgium, 2019.

38. Rist, S.; Jacobi, J. Selection of Food Systems in Bolivia and Kenya and Methods of Analysis; Centre for Development and Environment (CDE), University of Bern: Bern, Switzerland, 2016.

39. Rastoin, J.-L.; Ghersi, G. Le Système Alimentaire Mondial, Concepts et Méthodes, Analyses et Dynamiques; Editions Quæ: Paris, French, 2010.

40. SEDES. O que é o Bolsa Família. 2019. Available online: http://www.sedes.df.gov.br/bolsa-familia/ (accessed on 28 October 2019).

41. Oliveira, I.M.; de Moreira, M.R.A.; Hoffmann, E.; Barros, I.F.; Oliveira, R.A.; de SILVA, E.A. Desigualdade Social e Políticas Sociais: Estudos Sobre Expressões da Questão Social e Políticas de Enfrentamento a Pobreza na Cidade e no Campo; Paco: Jundiaí, Brazil, 2017.

42. Brasil. Assistência Técnica e Extensão Rural. 2018. Available online: http://www.agricultura.gov.br/assuntos/ ater (accessed on 8 January 2020).

43. Brasil. Decreto $n$ 7.535 2017, de 26 de Julho de Institui o Programa Nacional de Universalização do Acesso e Uso da Água-"Água para todos"; Congresso Nacional: Brasília, Brasil, 2011.

44. Brasil. Lei n 11.947, de 16 de Junho de 2009; Congresso Nacional: Brasília, Brasil, 2009.

45. Brasil. Decreto no 7.775, de 4 de Julho de 2012. Regulamenta o Art. 19 da Lei no 10.696 2012, de 2 de Julho de 2003, que Institui o Programa de Aquisição de Alimentos, e o Capítulo III da Lei no 12.512, de 14 de Outubro de 2011, e dá Outras Providências; Congresso Nacional: Brasília, Brasil, 2012.

46. Peraci, A.S.; Bittencourt, G.A. Family Farming and Price Guarantee Programs in Brazil: The Food Acquisition Program (PAA). In Fome Zero: The Brazilian Experience; Da Silva, J.G., Del Grossi, M.E., De França, C.G., Eds.; MDA/FAO: Brasília, Brazil, 2011; pp. 193-224.

47. Casa Nova. O Município. Prefeitura de Casa Nova. 2019. Available online: http://www.casanova.ba.gov.br/ detalhe-da-materia/info/a-cidade/6501 (accessed on 15 October 2019).

48. IBGE. Censo Demográfico 2010; Instituto Brasileiro de Geografia e Estatistica: Rio de Janeiro, Brazil, 2010.

49. IBGE. Síntese de Indicadores Sociais: Uma Análise das Condições de vida da População BrasileiraInstituto; Brasileiro de Geografia e Estatística: Rio de Janeiro, Brasil, 2019.

50. Garcez, A.N.R. Fundo de Pasto: Um Projeto de Vida Sertanejo; INTERBA/SEPLANTEC/CAR: Salvador, Brazil, 1987.

51. Cotrin, D.V.N. O Pastoreio Comunitário em Uauá: Uma Expressão da Subordinação do Trabalho ao Capital. Master's Thesis, Ciências Sociais, UFBA, Salvador, Brazil, 1991.

52. Downe-Wamboldt, B. Content analysis: Method, applications, and issues. Health Care Women Int. 1992, 13, 313-321. [CrossRef] [PubMed]

53. UNEP. Food Systems and Natural Resources. A Report of the Working Group on Food Systems of the International Resource Panel; United Nations Environment Programme: Nairobi, Kenya, 2016.

54. FAO. Leaving no one behind: Achieving gender equality for food security 1992, nutrition and sustainable agriculture. In Proceedings of the FAO Conference, 40th Session, Rome, Italy, 3-8 July 2017.

55. Panzutti, N.D.P.M. Mulher rural: Eminência oculta. Cadernos CERU 1997, 8, 59-79.

56. Silva, C.; Portella, A.P. Divisão sexual do trabalho em áreas rurais no Nordeste brasileiro. In Agricultura Familiar e Gênero: Práticas, Movimentos e Políticas Públicas; Scott, P., Cordeiro, R., Eds.; Universitária da UPE: Recife, Brazil, 2010; pp. 127-144.

57. Gittinger, P.J. Household Food Security and the Role of Women; World Bank: Washington, DC, USA, 1990.

58. FAO. Gender Key for Sustainability and Food Security—A New Framework for Development; Food \& Agriculture Organization: Rome, Italy, 1997. 
59. FAO. Women and sustainable food security. In Women in Development Service, Women and Population Division; Food \& Agriculture Organization: Rome, Italy, 2007.

60. Jiggins, J.; Samanta, R.K.; Olawoye, J.E. Improving women farmers' access to extension services. In Improving Agricultural Extension: A Reference Manual; Swanson, B.E., Bentz, R.P., Sofranko, A.U., Eds.; Food and Agricultural Association of the United Nations: Rome, Italy, 1997; pp. 73-81.

61. Perrot, M. As Mulheres ou os Silêncios da História; Edusc: Florianópolis, Brazil, 2005.

62. Bartholo, L.; Passos, L.; Fontoura, N. Bolsa Família, Autonomia Feminina e Equidade de Gênero: O que Indicam as Pesquisas Nacionais? Instituto de Pesquisa Econômica Aplicada: Rio de Janeiro, Brazil, 2017.

63. MDS. Bolsa Família: Benefícios. Available online: http://mds.gov.br/assuntos/bolsa-familia/o-que-e/ beneficios (accessed on 1 May 2020).

64. Chant, S. The 'Feminisation of Poverty' and the 'Feminisation' of Anti-Poverty Programmes: Room for Revision? J. Dev. Stud. 2008, 44, 165-197. [CrossRef]

65. Crenshaw, K. Documento para o encontro de especialistas em aspectos da discriminação racial relativos ao gênero. Rev. Estud. Fem. Florianópolis 2002, 10, 171-188. [CrossRef]

66. Dalton, R.J. Citizen Politics: Public Opinion and Political Parties in Advanced Industrial Democracies; Cq Press: Los Angeles, CA, USA, 2014.

67. Druckman, J.N.; Lupia, A. Preference formation. Annu. Rev. Political Sci. 2000, 3, 1-24. [CrossRef]

68. Goodin, S.M.; Van Denburg, A.; Murnen, S.K.; Smolak, L. "Putting on" sexiness: A content analysis of the presence of sexualizing characteristics in girls' clothing. Sex Roles 2011, 65, 1-12. [CrossRef]

69. Woortmann, E.F.; Woortmann, K. O Trabalho da Terra: A Lógica e a Simbólica da Lavoura Camponesa; Editora da UNB: Brasília, Brazil, 1997.

(C) 2020 by the authors. Licensee MDPI, Basel, Switzerland. This article is an open access article distributed under the terms and conditions of the Creative Commons Attribution (CC BY) license (http://creativecommons.org/licenses/by/4.0/). 